\section{Sand Shinnery Oak Response to Silvex Sprays of Varying Characteristics $^{1}$}

\section{J. SCIFRES 2}

Assistant Professor, Department of Range Science, Texas A\&M University, College Station.

\section{Highlight}

Silvex at $0.5 \mathrm{lb}$./acre applied in diesel oil, diesel oil:water emulsion, water, or water plus surfactant controlled sand shinnery oak in the Rolling Plains of Texas. Decreasing the silvex rate from $0.5 \mathrm{lb} . /$ acre progressively decreased sand shinnery oak control. Addition of 0.25 or $0.5 \mathrm{lb}$./acre ammonium thiocyanate did not enhance the effectiveness of $0.5 \mathrm{lb}$./acre silvex on sand shinnery oak.

Sand shinnery oak (Quercus havardii Rydb.) infests about 1.5 million acres of rangeland in the High and Rolling Plains of Texas (Rechenthin and Smith, 1967). Dense infestations with stems 2 to $4 \mathrm{ft}$ tall completely dominate many sites with deep sand or where sand is underlain by a shallow clay layer. Forage production may be reduced by more than $60 \%$ in such infestations (Robison and Fisher, 1968). Aerial applications of 2,4,5-T are most commonly used for control of sand shinnery oak. However, repeated applications are required for effective control and 2,4,5-T is less effective than 2-(2,4,5-trichlorophenoxy) propionic acid (silvex).

A diesel oil:water (1:4) emulsion is used by most ranch managers in northwest Texas for standard application of herbicides to woody plants. Total spray solution usually does not exceed 5 gal/acre. The emulsion is more effective than water for foliar sprays to honey mesquite (Prosopis glandulosa Torr. var. glandulosa) (Fisher et al., 1959). However, the emulsion does not enhance the effectiveness of silvex on small soapweed (Yucca glauca Nutt.) (Robison, 1968). No data were available to

\footnotetext{
${ }^{1}$ Approved by the Director, Texas Agr. Exp. Sta. as Technical Article 9247. Received July 10, 1971 .

2 The author gratefully acknowledges the cooperation of Jim Humphries, Pitchfork Land and Cattle Co., Guthrie, Texas in making areas available for study. Technical assistance in conducting this research was provided by $R$. R. Hahn, J. H. Brock and J. C. Halifax, Texas Agr. Exp. Sta., Lubbock and College Station.
}

substantiate the need for diesel oil when spraying sand shinnery oak. Diesel oil represents only $\$ 0.09$ to $\$ 0.16$ of the usual $\$ 2.75$ to $\$ 3.25$ application cost for $0.5 \mathrm{lb}$./acre $2,4,5-\mathrm{T}$ or silvex but a reduction in hauling and dispensing equipment would be realized without diesel oil.

Ammonium thiocyanate disrupts carbohydrate metabolism and photosynthesis ( $\mathrm{Wu}$ and Basler, 1969) and evidently enhances translocation of 2,4,5-T in some woody species (Basler et al., 1967). The possibility of enhancing the phytotoxicity of 2,4,5-T to honey mesquite with ammonium thiocyanate was indicatcd by Robison (1965). Elwell (1968) showed that ammonium thiocyanate increased the effectiveness of 2,4,5-T on winged elm (Ulmus alata Michx.). However, no data were available as to the performance of silvex in the presence of ammonium thiocyanate.

The objectives of this study were to a) compare the reaction of sand shinnery oak to varying rates of silvex, b) compare the phytotoxicity of silvex in diesel oil:water emulsions with diesel oil only, water only and water plus surfactant and c) evaluate the influence of ammonium thiocyanate on the phytotoxicity of silvex to sand shinnery oak.

\section{Material and Methods}

The study site is located in the Rolling Red Plains physiographic province of northwest Texas. The soil grades from deep sand in the lowlands to sand underlain by a clay layer on hillsides. The soil is slightly acid and low in organic matter. Vegetation is dominated by sand shinnery oak and little bluestem (Andropogon scoparius Michx.) with scattered small soapweed, sand sagebrush (Artemisia filifolia Torr.) and plains pricklypear (Opuntia polyacantha Haw.).

In all cases, experiments were designed as randomized complete blocks with 17 by $75 \mathrm{ft}$ plots replicated four times. Silvex was always applied in $21 \mathrm{gal} /$ acre carrier with a truck-mounted sprayer.

Silvex at $0,0.125,0.25$ and $0.5 \mathrm{lb}$./acre was applied in May, 1969 and the study was duplicated in 1970 . Herbicide was applied in diesel oil:water (1:4) emulsion.

In another study, plots were treated with silvex at 0.5 lb./acre in a diesel oil:water emulsion, diesel oil only, water only, or water plus $0.5 \%$ (v/v) nonionic surfactant. Controls included untreated plots and plots sprayed with diesel oil not containing herbicide.

In a third study, 0.25 or $0.5 \mathrm{lb}$./acre of ammonium thiocyanate was combined with $0.5 \mathrm{lb}$./acre of silvex and compared to $0.5 \mathrm{lb}$./acre silvex alone and ammonium thio- 
Table 1. Sand shinnery oak stem densities (thousands/ acre) and estimated canopy reduction (\%) 1 and 2 years after treatment with various rates (lb./acre) of silvex in a diesel oil:water (1:4) emulsion.

\begin{tabular}{|c|c|c|c|c|}
\hline \multirow[b]{2}{*}{ Rate } & \multicolumn{2}{|c|}{ Density $^{1}$} & \multicolumn{2}{|c|}{ Canopy reduction } \\
\hline & 1 year & 2 years & 1 year & 2 years \\
\hline 0 & $64.3 \mathrm{a}$ & $64.7 \mathrm{a}$ & 0 & 0 \\
\hline 0.125 & 60.1 a & 52.6 a & 25 & 22 \\
\hline 0.25 & $48.6 \mathrm{~b}$ & $36.4 \mathrm{ab}$ & 62 & 43 \\
\hline 0.5 & $20.2 \mathrm{c}$ & $24.3 \mathrm{~b}$ & 93 & 82 \\
\hline
\end{tabular}

${ }^{1}$ Means within a column followed by the same letter are not significantly different at the $5 \%$ level.

cyanate alone. Silvex-ammonium thiocyanate combinations were applied in the diesel oil:water (1:4) emulsion.

Total canopy damage from the sprays was estimated 30 days and 1 year after treatment. Approximately 1 year after 1970 treatments and 2 years after 1969 treatments, density of live sand shinnery oak stems was recorded from two, $1 \mathrm{~m}$ quadrats in all plots.

\section{Results and Discussion}

One year after treatment, reduction in density of live sand shinnery oak stems was related in a linear fashion to silvex application rates of $0.5 \mathrm{lb}$./ acre or less (Table 1). If linearity in response had included higher rates, an estimated $0.7 \mathrm{lb} /$ acre would be required for complete control. However, past research has shown that control with $1 \mathrm{lb}$./ acre silvex is usually no better than with $0.5 \mathrm{lb}$./ acre (Robison and Fisher, 1968). On that basis, rates higher than $0.5 \mathrm{lb}$./acre were not studied.

Densities of sand shinnery oak stems after application of silvex at $0.125 \mathrm{lb}$./acre were not significantly different from untreated areas (Table 1). The low silvex rate reduced the canopy by about $25 \%$ at 30 days after treatment. Canopy reduction did not change 1 and 2 years after application of $0.125 \mathrm{lb}$./acre. The canopy was reduced by about $60 \%$ the year of treatment with $0.25 \mathrm{lb}$./acre silvex but foliar area began to recover after 2 years.

Silvex at $0.5 \mathrm{lb}$./acre was the most effective rate for reduction of sand shinnery oak canopy and stem density (Table 1). Application of $0.5 \mathrm{lb} . /$ acre in a diesel oil:water (1:4) emulsion reduced the canopy by over $90 \%$ at 30 days and 1 year after treatment. Over $80 \%$ reduction was evident 2 years after herbicide application. Reduction in density of live stems ranged from $70 \%$ after 1 year to $75 \%$ at 2 years.

No silvex rate reduced sand shinnery oak regrowth from rhizome tissue. New shoots comprised about $5 \%$ of the density of untreated areas and about $25 \%$ of density in treated plots 2 years after application of $0.5 \mathrm{lb}$./acre silvex.

Carriers studied did not alter the effectiveness
Table 2. Sand shinnery oak stem densities (thousands/ acre) after 1 and 2 years and estimated canopy reduction (\%) 30 days and 2 years after treatment with $0.5 \mathrm{lb} . /$ acre silvex in various carriers at $21 \mathrm{gal} / \mathrm{acre}$.

\begin{tabular}{|c|c|c|c|c|}
\hline \multirow[b]{2}{*}{ Carrier } & \multicolumn{2}{|c|}{$\begin{array}{l}\text { Density after } \\
\text { treatment }^{1}\end{array}$} & \multicolumn{2}{|c|}{$\begin{array}{l}\text { Canopy reduction } \\
\text { after treatment }\end{array}$} \\
\hline & 1 year & 2 years & 30 days & 2 years \\
\hline Untreated check & 80.9 a & $68.8 \mathrm{a}$ & 0 & 0 \\
\hline Diesel oil check 2 & $80.9 \mathrm{a}$ & $68.6 \mathrm{a}$ & 5 & 5 \\
\hline Diesel oil & $28.3 \mathrm{~b}$ & $21.4 \mathrm{~b}$ & 97 & 73 \\
\hline Water & $24.3 \mathrm{~b}$ & $24.6 \mathrm{~b}$ & 95 & 75 \\
\hline $\begin{array}{l}\text { Diesel oil:water } \\
\quad(1: 4) \text { emulsion }\end{array}$ & $20.6 \mathrm{~b}$ & $24.3 \mathrm{~b}$ & 89 & 75 \\
\hline $\begin{array}{c}\text { Water }+0.5 \% \\
\text { surfactant }\end{array}$ & $24.3 \mathrm{~b}$ & $24.8 \mathrm{~b}$ & 99 & 75 \\
\hline
\end{tabular}

${ }^{1}$ Means within a column followed by the same letter are not significantly different at the $5 \%$ level. First year reaction is average of two studies.

${ }^{2}$ Applied without silvex at $21 \mathrm{gal} / \mathrm{acre}$.

of silvex on sand shinnery oak (Table 2). Initial canopy reduction ranged from 80 to $90 \%$ and was reduced to about $75 \% 2$ years after treatment regardless of carrier. Diesel oil is considered phytotoxic but caused only minor foliar damage when applied without silvex. Addition of diesel oil or surfactant apparently did not increase retention or foliar absorption of silvex.

Addition of 0.25 or $0.5 \mathrm{lb}$./acre ammonium thiocyanate did not improve control of sand shinnery oak with $0.5 \mathrm{lb}$./acre silvex. Both materials dispersed readily in the carrier emulsion and were well agitated during application. Ammonium thiocyanate alone at 0.25 or $0.5 \mathrm{lb}$./acre was not phytotoxic to sand shinnery oak.

These data indicate that at least $0.5 \mathrm{lb}$./acre silvex is required for effective sand shinnery oak control into the second growing season. Use of a diesel oil:water emulsion as carrier was not advantageous since aqueous silvex sprays provided effective control.

\section{Literature Cited}

Basler, E. P., P. W. Santelmann, A. Badiei, and E. W. MCCoRD. 1967. Effect of ammonium thiocyanate on the translocation of 2,4,5-T in blackjack oak and winged elm. Proc. S. Weed Conf. 20:382-386.

Elwell, H. M. 1968. Winged elm control with picloram and 2,4,5-T with and without additives. Weed Sci. 16: $131-133$.

Fisher, C. E., C. H. Meadors, R. Behrens, E. D. Robison, P. T. Marion, and H. L. Morton. 1959. Control of mesquite on grazing lands. Texas Agr. Exp. Sta. Bull. 935. $24 \mathrm{p}$.

Rechenthin, C. A., And H. N. Smith. 1967. Grassland restoration. V. Effect on water yield and supply. U.S. Dep. Agr., Soil Cons. Serv. Unnumbered bulletin. Temple, Texas. $46 \mathrm{p}$. 
Robison, E. D. 1965 . Field response of mesquite to varying combinations of 2,4,5-T and ammonium thiocyanate. Proc. S. Weed Conf. 18:293-298.

Robison, E. D. 1968. Chemical control of yucca in the Texas panhandle. Texas Agr. Exp. Sta. PR-2588 in Brush Research in Texas, 1968. 18-21.
Robison, E. D., ANd C. E. Fisher. 1968. Chemical control of sand shinnery oak. Texas Agr. Exp. Sta. PR-2583 in Brush Research in Texas, 1968. 5-8.

Wu, Y., AND E. Basler. 1969. Effects of ammonium thiocyanate on carbohydrate metabolism in the cotton plant. Weed Sci. 17:362-365. 